\title{
Induction of ebolavirus cross-species immunity using retrovirus-like particles bearing the Ebola virus glycoprotein lacking the mucin-like domain
}

\author{
Wu Ou ${ }^{1}$, Josie Delisle 1 , Jerome Jacques², Joanna Shih ${ }^{3}$, Graeme Price ${ }^{1}$, Jens H Kuhn, Vivian Wang ${ }^{5}$, \\ Daniela Verthelyi ${ }^{5}$, Gerardo Kaplan ${ }^{2}$ and Carolyn A Wilson ${ }^{1 *}$
}

\begin{abstract}
Background: The genus Ebolavirus includes five distinct viruses. Four of these viruses cause hemorrhagic fever in humans. Currently there are no licensed vaccines for any of them; however, several vaccines are under development. Ebola virus envelope glycoprotein $\left(\mathrm{GP}_{1,2}\right)$ is highly immunogenic, but antibodies frequently arise against its least conserved mucin-like domain (MLD). We hypothesized that immunization with MLD-deleted $\mathrm{GP}_{1,2}$ (GP $\triangle M L D)$ would induce cross-species immunity by making more conserved regions accessible to the immune system.
\end{abstract}

Methods: To test this hypothesis, mice were immunized with retrovirus-like particles (retroVLPs) bearing Ebola virus GP $\triangle M L D$, DNA plasmids (plasmo-retroVLP) that can produce such retroVLPs in vivo, or plasmo-retroVLP followed by retroVLPS.

Results: Cross-species neutralizing antibody and $\mathrm{GP}_{1,2}$-specific cellular immune responses were successfully induced.

Conclusion: Our findings suggest that GPAMLD presented through retroVLPs may provide a strategy for development of a vaccine against multiple ebolaviruses. Similar vaccination strategies may be adopted for other viruses whose envelope proteins contain highly variable regions that may mask more conserved domains from the immune system.

Keywords: Ebola, Ebolavirus, Envelope glycoprotein, Filovirus, Mucin-like domain, Retrovirus, Virus-like particles, DNA vaccine

\section{Background}

The genus Ebolavirus is a member of the family Filoviridae. Ebolavirus includes five species: Zaire ebolavirus (Ebola virus, EBOV), Sudan ebolavirus (Sudan virus, SUDV), Taï Forest ebolavirus (Taï Forest virus, TAFV), Reston ebolavirus (Reston virus, RESTV), and Bundibugyo ebolavirus (Bundibugyo virus, BDBV) [1]. Except for RESTV, the ebolaviruses cause viral hemorrhagic fever (VHF) in humans. In particular, EBOV infection causes lethality up to $90 \%[2,3]$. Other than supportive care, there

\footnotetext{
* Correspondence: carolyn.wilson@fda.hhs.gov

'Division of Cellular and Gene Therapies, Center for Biologics Evaluation and Research, Bldg. 29B, Room 5NN22, 8800 Rockville Pike, Bethesda, MD 20892 , USA

Full list of author information is available at the end of the article
}

is no FDA-approved treatment or vaccine for ebolavirus infections.

Ebolaviruses have been categorized by NIH/NIAID as Category A Priority Pathogens because they could be misused for the development of biological weapons. The availability of a vaccine that provides cross-protection against different ebolaviruses is essential for preparedness against natural outbreaks and acts of bioterrorism. While there has been progress in recent years towards development of ebolavirus vaccines, most vaccine candidates are based on antigens from one or two ebolaviruses only. Though some vaccine candidates have demonstrated evidence of crossprotection, many induce species-specific immune responses and protection [4-6].

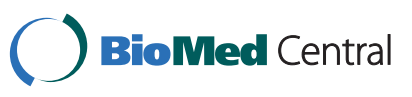

(c) 2012 Ou et al; BioMed Central Ltd. This is an Open Access article distributed under the terms of the Creative Commons Attribution License (http://creativecommons.org/licenses/by/2.0), which permits unrestricted use, distribution, and reproduction in any medium, provided the original work is properly cited. 
The viral envelope glycoprotein $\mathrm{GP}_{1,2}$ is either a component of, or the sole viral antigen in many ebolavirus candidate vaccines. $\mathrm{GP}_{1,2}$ is presented on the surface of virions as trimers of $\mathrm{GP}_{1}-\mathrm{GP}_{2}$ heterodimers that are linked together through a disulfide bond [7]. The C-terminal region of $\mathrm{GP}_{1}$, designated as the mucin-like domain (MLD), is highly variable among different ebolaviruses and is highly $\mathrm{N}$ - and $\mathrm{O}$-glycosylated. The MLD is thought to form a "glycan cap" that is hypothesized to prevent antibody binding to those epitopes shielded from recognition by the immune system, suggesting that the MLD with its glycan cap provides a mechanism of immune evasion [8-10]. In addition, the MLD-glycan cap appears to be a target for antibody responses to ebolaviruses, and may thus also serve as a decoy to divert an antibody response to the more conserved regions of the envelope [11-14]. The MLD is dispensable for $\mathrm{GP}_{1,2}$-mediated virus entry [7,15-17], and there appear to be no other known functions for the MLD other than immune shielding/evasion. We hypothesized that deletion of the MLD would expose the more conserved regions of $\mathrm{GP}_{1,2}$, such as the receptorbinding site $[8,15,18,19]$, and induce an immune response to these more conserved regions that may result in crossspecies immunity.

Virus-like particles (VLPs) are ideal immunogens because 1) they mimic wild-type pathogens in morphology and thus display antigens in their native conformations; 2) the particle size allows for efficient uptake by antigen presenting cells; and 3) presentation of the multimeric form of antigens on VLPs may cross-link B cell receptors and provide a strong stimulation signal $[20,21]$. In fact, both the FDA-approved hepatitis B virus and human papillomavirus vaccines are based on VLPs [20,22]. DNA vaccines are also advantageous because they induce both humoral and cellular immune responses, are easy to manufacture at large scale and at low cost, and are stable at room temperature, thus obviating the need for a cold chain for vaccine distribution and storage [23-25]. To combine the advantages of VLP and DNA-based vaccines, several studies have used a new vaccination strategy, whereby the DNA used for immunization encodes proteins allowing for formation of VLPs in vivo. Such DNA vaccines alone or as part of DNA prime-VLP boost vaccination strategies have been tested and shown to induce protective immune responses for various viruses, for example, hepatitis $C$ virus [26-31], but this strategy has not been tested for ebolavirus [32-38].

Although both wild-type Ebola virus $\mathrm{GP}_{1,2}$ and GP $\triangle$ MLD are efficiently incorporated into retrovirus particles, e.g. murine leukemia virus (MLV) [39-41], Ebola virus glycoprotein-pseudotyped VLPs based on retroviral vectors have not been explored as vaccine candidates. In this study, we tested the relative immunogenicity in mice of VLPs based on MLV, termed retrovirus-like particles
(retroVLPs) bearing GP $\triangle$ MLD of Ebola virus, which were generated in vitro (retroVLPs) or in vivo after injection of DNA plasmids that can produce retroVLPs in vivo (plasmo-retroVLP). In addition, we evaluated the immune response after immunization with plasmo-retroVLP followed by immunization with retroVLPs. For simplicity, retroVLPs and plasmo-retroVLPs are referred to as VLP and DNA, respectively, throughout the rest of this report. We compared these vaccines in mice and demonstrated that VLP, or the combination of DNA followed by VLP were both able to induce cross-species neutralizing antibody and $\mathrm{GP}_{1,2}$-specific IFN- $\gamma$ production.

\section{Results}

Antigen preparation and immunization

VLPs were produced by transient transfection of HEK 293T cells with two plasmids: one encoding Ebola virus GP $\triangle \mathrm{MLD}$ (Figures 1A and 1B) and the other encoding the gag-pol polyprotein precursor of the Moloney murine leukemia virus (MLV) core and enzymatic proteins (Figure 1C). Since the retroviral vector genome was not used to produce the VLPs, there is no risk of retroviral vectormediated genome integration associated. To maximize the yield of VLPs and their incorporation of GP $\triangle M L D$, the ratio of the two plasmids used for transfection was optimized to 2:1, gag-pol:env (see Materials and Methods for description; data not shown). After concentration and partial purification, the VLP preparation was checked for purity with silver stained SDS-PAGE gels and the incorporation of GP $\triangle$ MLD into the VLPs was confirmed by western blot (Figure 1D). Values for residual endotoxin for VLPs, plasmids, and CpGs were $0.86 \mathrm{EU} / \mathrm{ml}, 0.32 \mathrm{EU} / \mathrm{ml}$, and $0.27 \mathrm{EU} / \mathrm{ml}$, respectively.

\section{Antibody response to EBOVGPAMLD after immunization of mice}

Immunization dose, routes and schedule for immunization and sample collection are depicted in Figure 2.

As shown in Figures 3A and 3B, the antibody titer of the sera pooled from the mice primed twice with DNA and boosted once with VLP (DNA/VLP group) was approximately 10 -fold that of the mice immunized with DNA alone (DNA group) (1:2000 vs. 1:256, respectively); there was no anti-GP1,2 antibody detected in the pooled sera from either the negative control $\mathrm{CpG}$, or the negative control CpG/PBS group.

To analyze the dynamics of the antibody response, we measured at different time points 1:64 dilutions of sera from the DNA group, and 1:2000 dilutions of sera from the DNA/VLP group. Figure 3C shows that the response among the DNA group climbed slowly and reached peak levels at about 14 weeks. In contrast, response of the DNA/VLP group peaked between 6-10 weeks then dipped but then responded well to a boost (Figure 3D). 


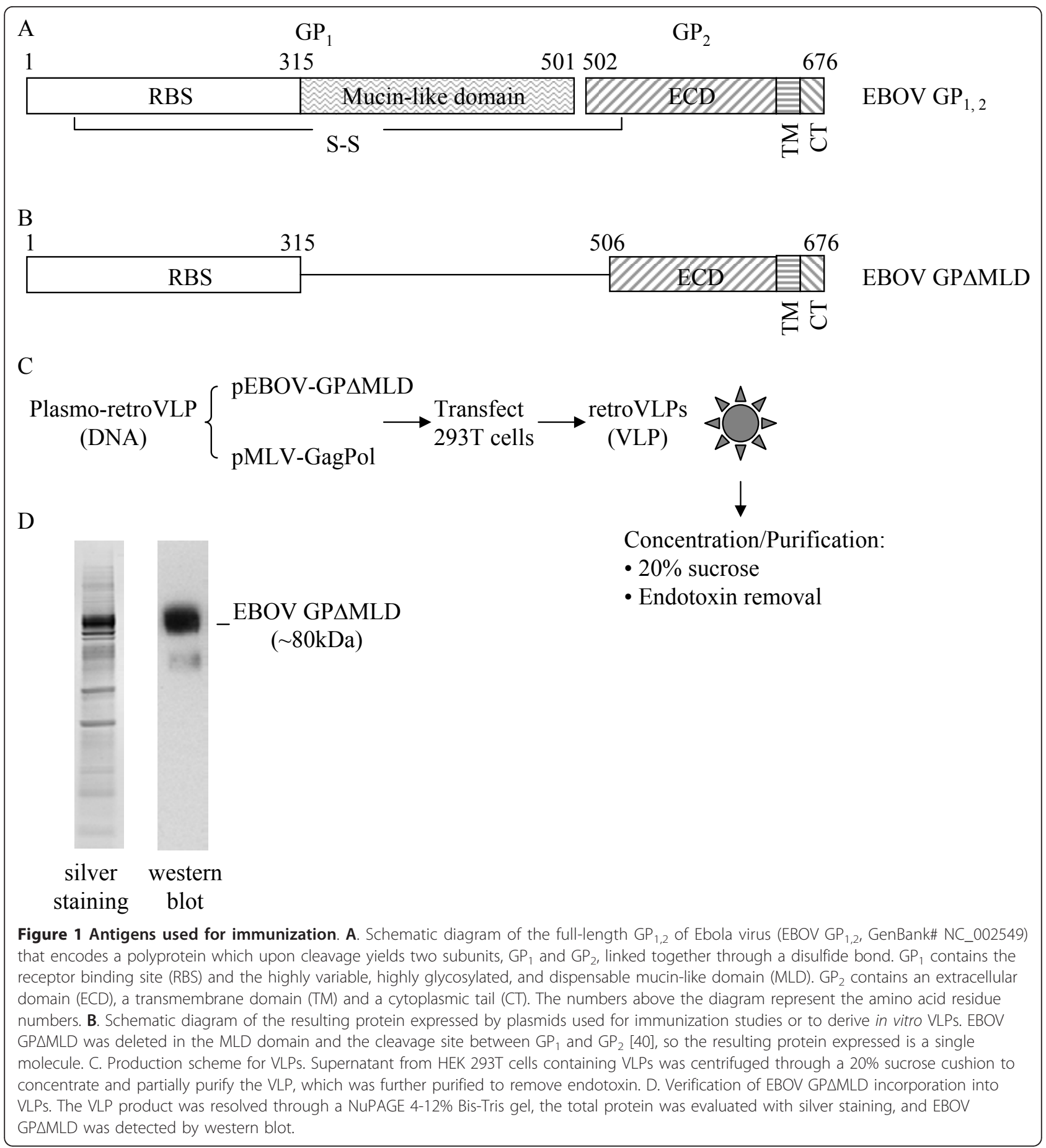

These data demonstrate that DNA/VLP induces a response in mice that is quantitatively and kinetically superior to that of DNA alone.

The sera collected from mice immunized with VLP alone resulted in comparable reactivity by ELISA to both the Fc control protein and the $\mathrm{GP}_{1,2}$ protein. Therefore, for the group of mice who were immunized with VLP alone (VLP group), the $\mathrm{GP}_{1,2}$-specific antibody response was evaluated by western blot from sera at the 10 week time point. Figure $3 \mathrm{E}$ shows that EBOV $\mathrm{GP}_{1,2}$ reactive antibody was detected when sera were diluted as high as 1:10,000. For comparison, sera collected at week 10 of the DNA/VLP group were reactive to EBOV $\mathrm{GP}_{1,2}$ at the 1:5,000 dilution, but only a faint band was detected with sera diluted to $1: 10,000$ (Figure $3 \mathrm{E}$ ). The dynamics of antibody response in the VLP group was 


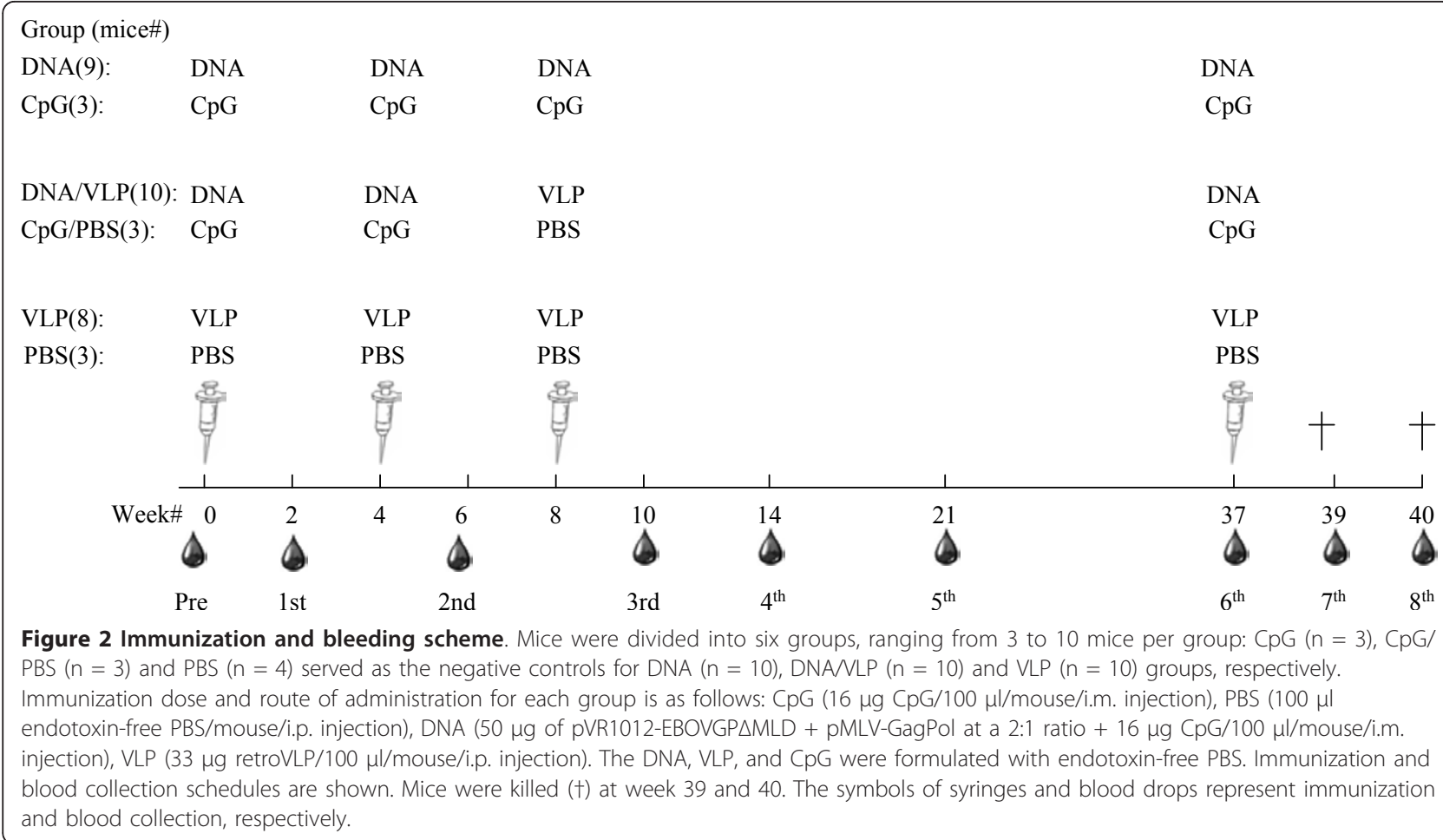

not tested because for some time points, there was insufficient serum for the western blots.

\section{Cross-species reactivity of the anti-EBOVGPAMLD antibody}

To test whether the anti-EBOV GP $\triangle$ MLD antibody can recognize the full-length $\mathrm{GP}_{1,2}$ of other ebolaviruses, the western blot was repeated with the lysate of cells transfected with one of the following plasmids encoding the full-length $\mathrm{GP}_{1,2}$ of EBOV, SUDV, TAFV or BDBV. As shown in Figure 4, sera from mice immunized with DNA/VLP or VLP alone detected the full-length $\mathrm{GP}_{1,2}$ of all ebolaviruses tested. It was not surprising that the bands for the lysate from EBOV $\mathrm{GP}_{1,2}$-expressing cells were the most intense (Figures $4 \mathrm{~A}$ and $4 \mathrm{~B}$ ), because the EBOV was the source of the immunogen, and conservation of the non-MLD domains among the ebolaviruses is not $100 \%$. As a control for transfection efficiency, we used the rabbit anti-GP $\mathrm{G}_{1,2}$ polyclonal antibody R.F88-2, because it was previously shown to be cross-reactive to all $\mathrm{GP}_{1,2} \mathrm{~s}$ used in this study [42]. Detection of similar band intensities in all lysates suggests similar levels of $\mathrm{GP}_{1,2}$ expression, with the exception of TAFV, which is somewhat lower (Figure 4C). Western blots using sera collected from control mice sera were negative (data not shown).

As shown in Figures $4 \mathrm{~A}$ and $4 \mathrm{~B}$, a TAFV $\mathrm{GP}_{1,2}$ fragment of approximately $50 \mathrm{kDa}$ was repeatedly detected by the immune sera but not by R.F88-2. Since R.F88-2 was raised by injecting a conserved 38 -mer $\mathrm{GP}_{1,2}$ peptide (aa72-109, [42]), the epitope on the TAFV fragment detected by the mice presumably is from a region outside of this domain, or the region that R.F88-2 recognizes is conformationally distinct.

\section{Neutralization activity of the sera from immunized mice}

The neutralization activity of sera from immunized mice was first tested using recombinant vesicular stomatitis virus (rVSV) after replacing its envelope $\mathrm{G}$ protein with EBOV GP ${ }_{1,2}$ (rVSV-ZEBOVGP) [43]. In the presence or absence of complement, titers of rVSV-ZEBOVGP were reduced by $90-100 \%$ by sera from the VLP group, and by $50-80 \%$ by sera from the DNA/VLP group (Figures $5 \mathrm{~A}$ and $5 \mathrm{~B})$. Whereas sera from mice immunized with DNA alone specifically neutralized rVSV-ZEBOVGP in the presence of complement (40\%), no neutralization was detected in the absence of complement (Figures 5A and $5 B)$. Surprisingly, there was an unexpected decrease in titer (40\%) observed for wild-type VSV control for sera from mice immunized with DNA, but not for sera from mice immunized with DNA/VLP (Figure 5C).

It was also unexpected that within the $\mathrm{CpG}$ control group, one out of three mice showed neutralization activity against wild-type VSV (Figure 5C), which persisted, albeit at a lower level, in the absence of complement (Figure 5D). In addition, individual variability was observed when sera from one of two mice in the DNA group and one in three individual mice in the CpG group collected at 


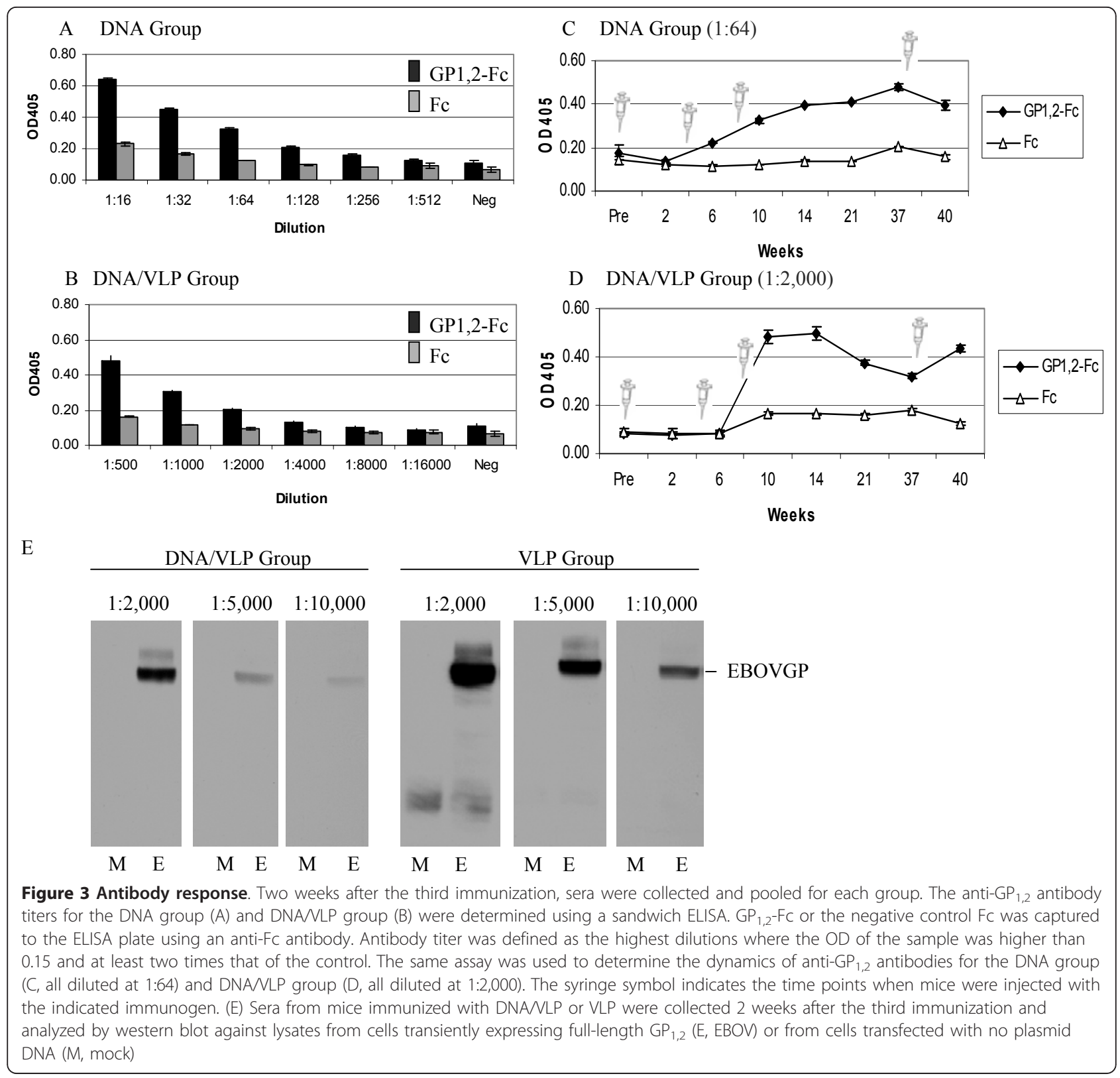

week 37, showing reproducible neutralization activity to wild-type VSV (Figure 5E).

To confirm and extend the observed neutralization of rVSV-ZEBOVGP to other ebolaviruses, the neutralization activity of the immune sera was also tested using MLV pseudotyped with the $\mathrm{GP}_{1,2}$ of different ebolaviruses or the G protein of VSV as a control for specificity. As shown in Figure 6, the pooled sera of the VLP group neutralized all ebolaviruses tested by approximately $40-95 \%$ at the $1: 25$ dilution. No neutralization was observed against control MLV pseudotypes carrying VSV G, indicating the neutralization observed is specific. The DNA/VLP group sera neutralized the MLV pseudotypes $60-80 \%$ for those carrying the $\mathrm{GP}_{1,2}$ of EBOV, TAFV, or BDBV, but not the SUDV $\mathrm{GP}_{1,2}$ or control envelopes. The DNA group sera did not neutralize any of the MLV pseudotyped viruses tested (data not shown).

\section{Cellular immune response against $\mathrm{GP}_{1,2}$}

To assess whether immunization with VLP or DNA can induce $\mathrm{GP}_{1,2}$-specific cellular immune responses, splenocytes were harvested from immunized mice at week 40 , and then stimulated with three $\mathrm{GP}_{1,2}$-specific peptides or no-peptide control, and the secretion of IFN- $\gamma$ was detected by ELISPOT. Consistent with the antibody response, a small but statistically significant increase in 


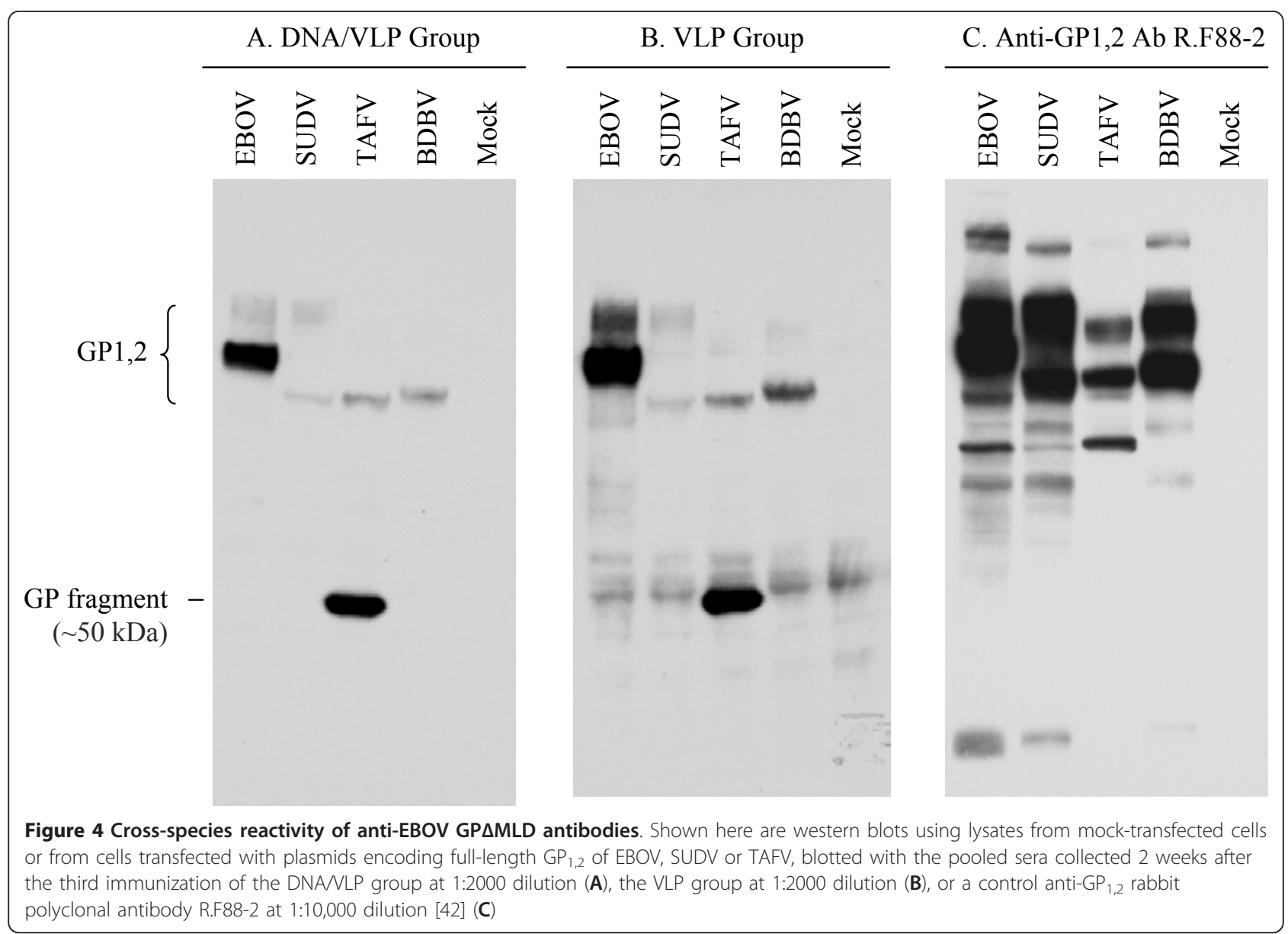

IFN- $\gamma$-secreting cells was detected in splenocytes harvested from both the VLP and DNA/VLP groups, but not the DNA or negative control groups (Figure 7).

\section{Discussion}

In this study we have compared three different vaccination strategies: VLPs alone, DNA that produces VLPs in vivo, or DNA followed by VLPs. We evaluated both the humoral immune response over time after a total of four immunizations, and the cellular immune response at week 40 upon completion of all immunizations. Using a combination of ELISA, western blot analysis, and two different types of neutralization assays, we were able to demonstrate that mice immunized with VLPs bearing the GP $\triangle \mathrm{MLD}$ of a single ebolavirus, EBOV, generated cross-reactive neutralizing antibodies to the fulllength GP of EBOV, as well as of the other ebolaviruses SUDV, TAFV, and BDBV. In addition, we showed that mice immunized with VLPs bearing GP $\triangle$ MLD developed a low, but detectable $\mathrm{GP}_{1,2}$-specific cellular immune response.

Our study did not include a challenge component, and therefore, we cannot claim that the vaccination strategy described here is protective. However, the detection of neutralizing antibodies in the range of 1:25 dilution of sera is comparable to levels of neutralizing antibodies observed in rodent and non-human primate challenge studies where protection was observed, suggesting that each of these strategies may protect against natural infection $[43,44]$.

The observation that sera from immunized animals neutralize VSV or MLV pseudotypes carrying full-length $\mathrm{GP}_{1,2}$, suggests that the induced antibodies recognize fulllength wild-type $\mathrm{GP}_{1,2}$. We had hypothesized that deleting the highly variable and highly immunogenic MLD may expose other antigenic determinants that are conserved and thus more likely to induce cross-reactive immune response. Our finding that sera from mice immunized with EBOV MLD-deleted $\mathrm{GP}_{1,2}$ could also cross-react with $\mathrm{GP}_{1,2}$ of other ebolaviruses by western blot and in some cases cross-neutralize suggests that indeed this may be the case.

The immunogenicity of the EBOV MLD-deleted $\mathrm{GP}_{1,2}$ has been previously studied $[11,45]$. Dowling et al. showed that wild-type EBOV GP 1,2 -immunized mice induced antibodies mainly against the MLD. However, 10 out 15 mice 


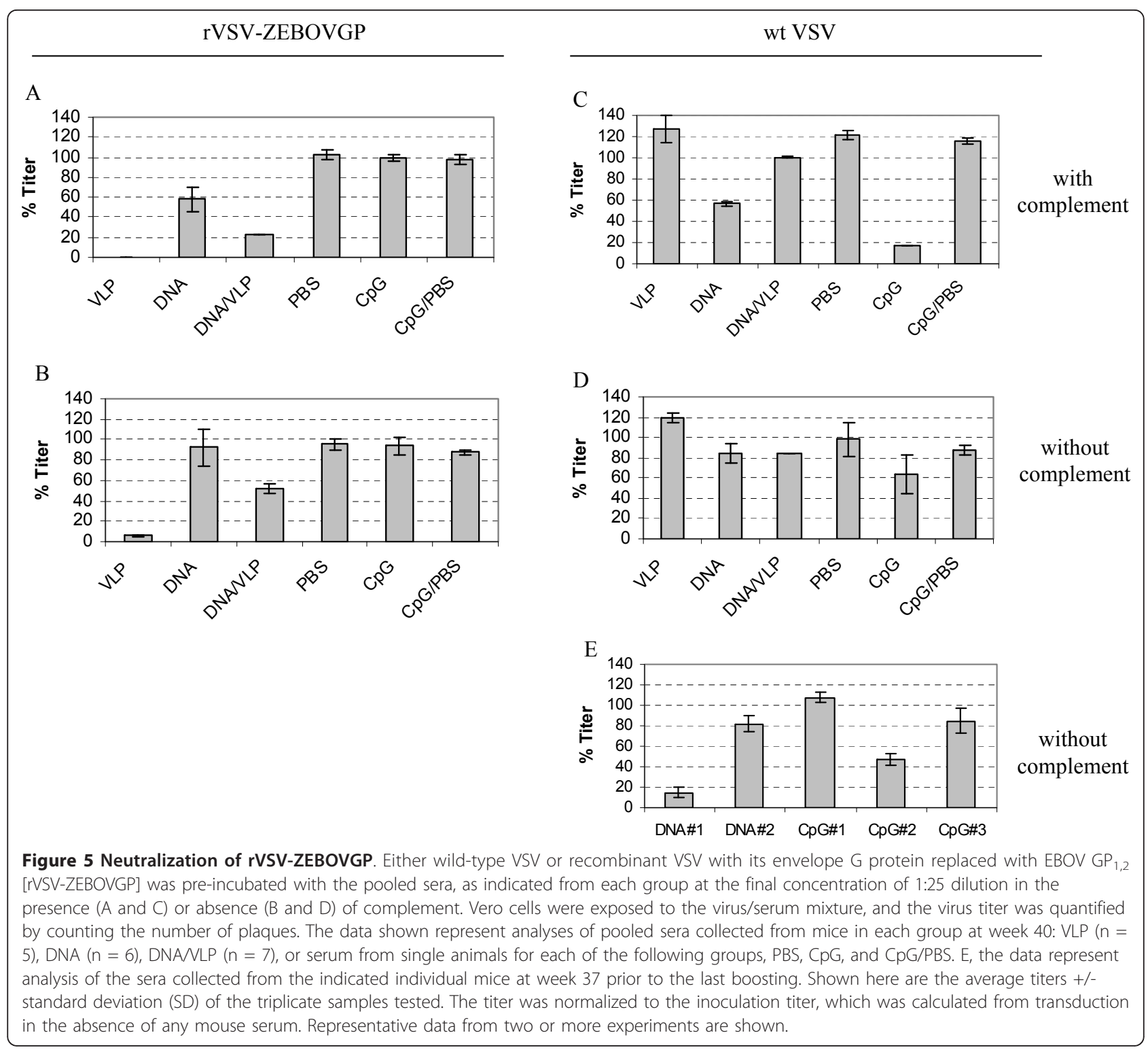

immunized with $\Delta 12$ (a $\mathrm{GP}_{1,2}$ in which amino acid residues 312-411 were deleted), eight out of 17 mice immunized with $\Delta 234$ (a GP 1,2 in which amino acid residues 342-462 were deleted) and five out of 17 mice immunized with $\Delta 1234$ (a GP 1,2 in which amino acid residues $312-462$ were deleted) survived lethal challenges with mouseadapted EBOV, suggesting the MLD is not absolutely required for inducing protective immunity. In this study, amino acid residues 316-505 of $\mathrm{GP}_{1,2}$ were deleted. A potentially significant difference between this study and the one by Dowling et al. is that the GP $\triangle$ MLD used in this study does not contain the cleavage site between $\mathrm{GP}_{1}$ and $\mathrm{GP}_{2}$, which would help stabilize the $\mathrm{GP}_{1,2}$ trimer and might stimulate the immune system more efficiently. Martinez et al. reported that the MLD plays a role in stimulating dendritic cells [45]. However, antibody and cellular immune responses were not determined. $\mathrm{GP}_{1,2}$ was not presented in the VLP format in either of the two mentioned studies.

Each of the three vaccination approaches used in this study has its own advantages and disadvantages. The VLP group induced the strongest immune responses in terms of antibody titer and the number of IFN- $\gamma$ secreting cells. However, the manufacturing of this type of vaccine is complex and costly. In addition, we observed non-specific reactivity making certain analyses of the immune response uninterpretable (i.e., ELISA could not be used). This is not surprising because retroviruses are well-documented to incorporate non-viral membrane proteins into viral particles [46-49]. The DNA group 


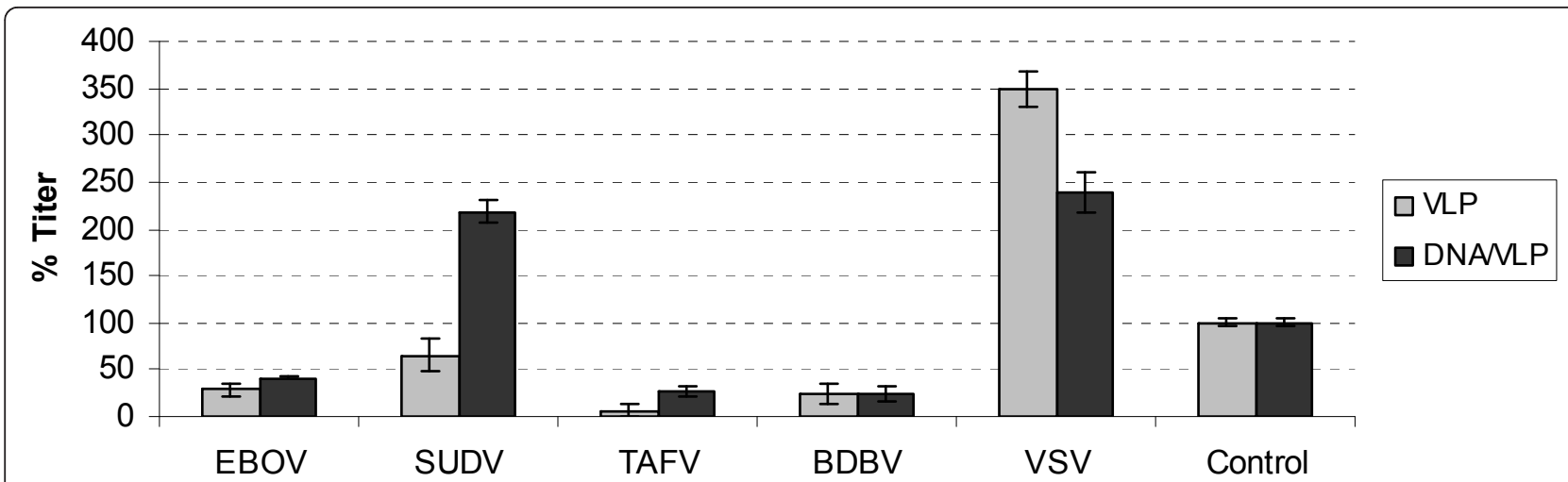

Figure 6 Neutralization of MLV pseudotyped virus bearing envelopes from different viruses. $\beta$-galactosidase-expressing MLV pseudotypes bearing the $\mathrm{GP}_{1,2}$ of EBOV, SUDV, TAFV, or BDBV or the G protein of VSV were pre-incubated with the pooled sera of each group $(V L P(n=5)$, DNA $(n=6)$, DNANLP $(n=7))$, which were collected at week 40 , at the final concentration of 1:25 dilution. The control group represents a pool of sera collected from one mouse in each of the negative control groups: CpG, CpG/PBS, and PBS. Vero cells were exposed to virus/antibody mixtures and the virus titer was quantified by counting the number of blue forming units (BFU) under microscope. Two or three replicates were used in each experiment. For each pseudotype, the titer observed in the presence of sera pooled from negative control mice was normalized to $100 \%$, and all other titers for that particular pseudotype are reported as relative to that value. Representative data from two or more experiments are shown.

had a detectable, but low titer antibody response 2 weeks after the second immunization. Though antibody was induced in the DNA group and could be detected by ELISA, its titer was too low to neutralize either recombinant VSV or pseudotyped MLV viruses at a 1:25 dilution. Lower dilutions were not tested. The titer of the DNA group may be low due to inefficient VLP production in vivo. The DNA/VLP group may be an ideal choice because that VLP was used only once, thus alleviating VLP production cost and avoiding the non-specific antibody response, while retaining a strong immune response to all the ebolaviruses tested (Figure 4).

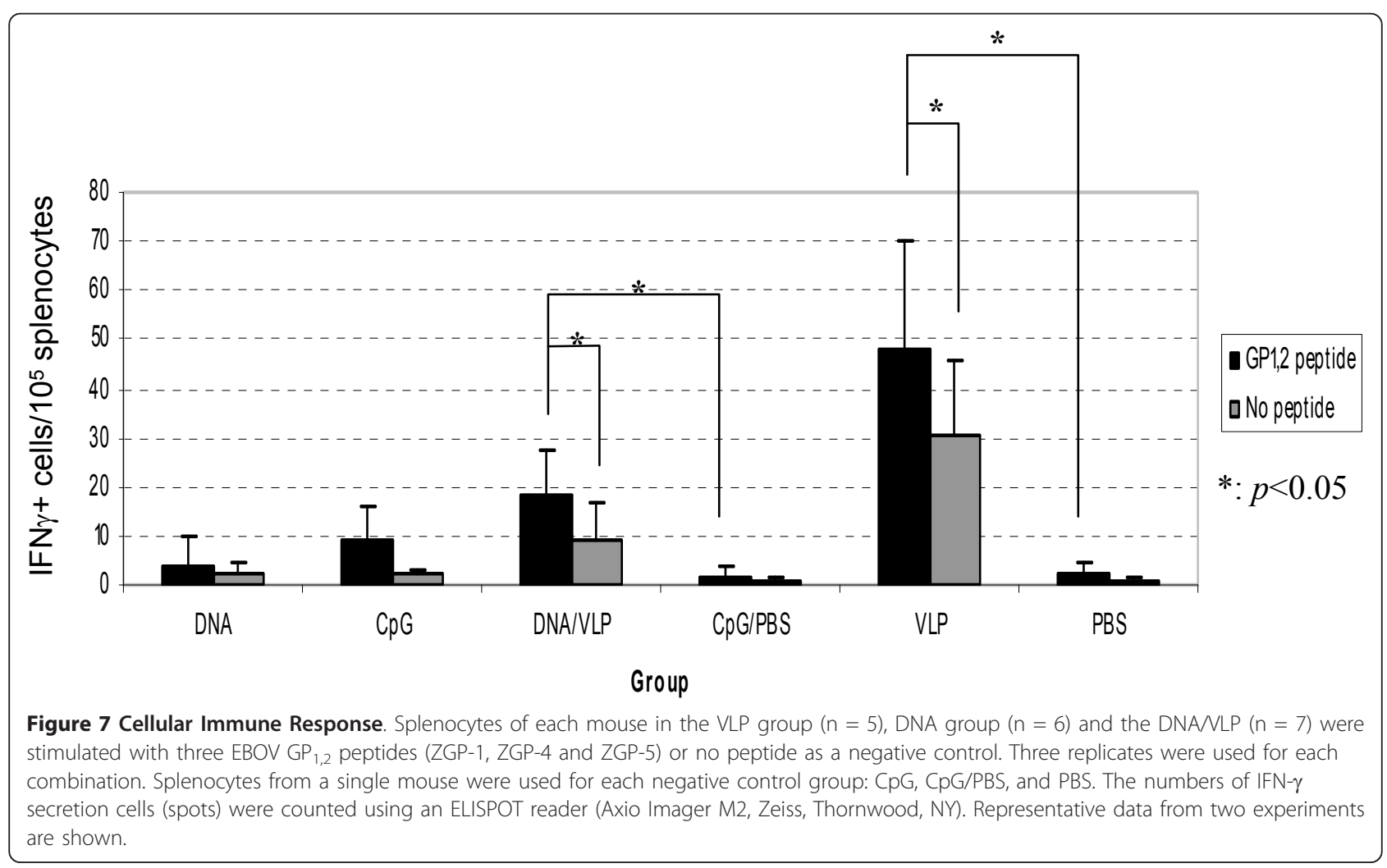


In support of greater specificity induced by the DNA/ VLP regimen, there were fewer background bands in the western blots from the DNA/VLP immunized mice than from the VLP group, probably because of the incorporation of murine "self antigens" on the in vivo produced VLPs, compared to human 293T cell-derived antigens on in vitro produced VLPs. Therefore, in vivo generated VLPs from DNA immunization would not induce strong antibody response to the non-viral components of the VLP because there was only one exposure of the immune system to foreign antigens on the in vitro produced VLPs. For the VLP alone group, however, there were multiple exposures of the immune system to foreign antigens on the in vitro produced VLPs, and therefore, higher antibody responses to these foreign antigens were observed.

It remains to be confirmed whether the immune responses induced by the vaccination strategies described in this study can protect immunized mice from virus challenge. If so, these strategies may be adopted for other viruses whose envelope proteins include highly variable domains that shield the more conserved and potentially immunogenic regions from recognition by the immune system. By deleting the highly variable regions, the relatively conserved regions of the envelope protein will be exposed and presented to the immune system through virus like particles.

\section{Conclusion}

Cross-species humoral and cellular immune responses were successfully induced using retrovirus-like particles (retroVLPs) bearing Ebola virus GP $\triangle \mathrm{MLD}$. The findings suggest that GP $\triangle$ MLD presented through retroVLPs may provide a strategy for development of a vaccine against multiple ebolaviruses. Similar vaccination strategies may be adopted for other viruses whose envelope proteins contain highly variable regions.

\section{Materials and methods \\ Cell culture}

Human embryonic kidney cells expressing the SV40 large T antigen (HEK 293T) (a gift from T. Dull, Cell Genesys, CA), African green monkey kidney epithelial cells (Vero cells [ATCC CCL-81]) and African green monkey kidney fibroblast-like cells expressing the SV40 T antigen (Cos7 cells [ATCC CRL-1651]) were maintained in Dulbecco's Modified Eagle's Medium (DMEM, Lonza, Walkersville, MD) supplemented with $10 \%$ heat-inactivated fetal bovine serum (FBS, HyClone, Logan, UT), 2 mM glutamine, $100 \mathrm{U} / \mathrm{ml}$ penicillin, and $100 \mu \mathrm{g} / \mathrm{ml}$ streptomycin (Lonza, Walkersville, MD). Cells cultures were grown at $37^{\circ} \mathrm{C}$ in a humidified $5 \% \mathrm{CO}_{2}$ incubator.

\section{Plasmid DNAs}

The pVR1012-EBOVGP, pVR1012-SUDVGP, and pVR1012-TAFVGP plasmids encode EBOV, SUDV, and
TAFV $\mathrm{GP}_{1,2}$, respectively, and were kindly provided by Gary Nabel (Vaccine Research Center, NIH, Bethesda, MD) and Anthony Sanchez (CDC, Atlanta, GA). pVR1012-EBOVGP $\triangle$ MLD encodes the EBOV MLDdeleted $\mathrm{GP}_{1,2}$ and was described previously [40]. pBDBV $\mathrm{GP}_{1,2}$ encodes wild-type BDBV $\mathrm{GP}_{1,2}$ and was previously described [42]. pMLV-GagPol is a Moloney murine leukemia virus (MLV)-based gag-pol expression plasmid and pRT43.2nls $\beta$ gal is a MLV-based packageable genome encoding $\beta$-galactosidase and a nuclear localization signal [50]. pVSV-G is a commercial plasmid from Clontech (Mountain View, CA), encoding the G glycoprotein of Vesicular stomatitis virus (VSV).

\section{Peptides}

The following EBOV $\mathrm{GP}_{1,2}$ peptides were synthesized and Reverse Phase HPLC-purified at the FDA CBER Core Facility: ZGP-1 (VSGTGPCAGDFAFHK, amino acid 141155) [51], ZGP-4 (LYDRLASTV, amino acid 161-169) and ZGP-5 (EYLFEVDNL, amino acid 231-239) [52].

\section{VLP and CpG production and characterization}

VLPs were produced by cotransfecting $16 \mu \mathrm{g}$ of pVR1012EBOVGP $\triangle$ MLD and $8 \mu \mathrm{g}$ pMLV-GagPol into HEK 293T cells at a density of $5 \times 10^{6}$ cells $/ 100 \mathrm{~mm}$ cell culture dish by using $60 \mu \mathrm{l}$ per dish of Lipofectamine 2000 (Invitrogen, Carlsbad, CA). Supernatants were collected 48 and $72 \mathrm{~h}$ post transfection, clarified through $0.45 \mu \mathrm{m}$-pore size filters, and concentrated by Amicon Ultracel $100 \mathrm{k}$ centrifugal filters (Millipore, Billerica, MA). The concentrated VLP-containing supernatants were centrifuged through a $20 \%$ (wt/vol) sucrose cushion in TNE buffer (10 mM Tris [pH 8.0], $1 \mathrm{mM}$ EDTA, $100 \mathrm{mM} \mathrm{NaCl}$ ) at $82,705 \times g$ in a Beckman XL-90 ultracentrifuge using a Beckman SW28Ti rotor. The resulting pellets were resuspended in endotoxin-free phosphate-buffered saline (PBS) (Teknova, Hollister, CA) and stored at $-80^{\circ} \mathrm{C}$. A total of ten batches of VLPs were generated, pooled together and total protein concentration was measured using the Bio-Rad DC Protein Assay Kit (Bio-Rad, Hercules, CA). Western blot and silver stain analyses were performed to characterize the purity and makeup of the purified VLPs. Briefly, 10, 1, and $0.1 \mu \mathrm{g}$ of the samples were denatured for $5 \mathrm{~min}$ at $95^{\circ} \mathrm{C}$ in 1× NuPAGE LDS Sample Buffer and 1× NuPAGE Sample Reducing Agent (Invitrogen, Carlsbad, CA), electrophoresed on a pre-cast NuPAGE 4-12\% Bis-Tris gel at $200 \mathrm{~V}$ and transferred to a PVDF membrane (Invitrogen, Carlsbad, CA) for $90 \mathrm{~min}$ at $30 \mathrm{~V}$. The membrane was probed with $35 \mathrm{ng} / \mathrm{ml}$ of an anti-GP 1,2 rabbit polyclonal antibody R.F88-2, which was raised by injecting a conserved 38-mer $\mathrm{GP}_{1,2}$ peptide (amino acid residues 72-109) [42], followed by incubation with goat anti-rabbit IgG conjugated with horse radish peroxidase (HRP) diluted at 1:10,000 (Thermo Scientific, Rockford, IL), developed with Western 
Lightning ${ }^{\mathrm{TM}}$ Plus Chemiluminescence Reagent (PerkinElmer, Waltham, MA), and subsequently exposed to a Kodak BioMax MR Film (Carestream Health, Rochester, NY). Likewise, a silver stain analysis was performed using the SilverQuest ${ }^{\mathrm{TM}}$ Silver Staining Kit (Invitrogen, Carlsbad, CA) according to the manufacturer's instructions. Phosphorothioate CpG ODN 1555 (5'-GCTAGACGTTA GCGT-3', underlined portion represents the active CpG motif) was synthesized at the CBER core facility. Endotoxin was removed using the ToxinEraser ${ }^{\mathrm{TM}}$ Endotoxin Removal Kit and residual endotoxin was measured using the ToxinSensor ${ }^{\mathrm{TM}}$ Chromogenic LAL Endotoxin Assay Kit, following the manufacturers' manuals (GenScript, Piscataway, NJ).

\section{Animals and vaccination experiment}

Female BALB/c $\left(\mathrm{H}-2^{\mathrm{d}}\right)$ mice, aged 6-8 weeks, were obtained from Charles River Laboratories (Germantown, $\mathrm{MD}$ ) and divided randomly into six vaccination groups. For VLP immunizations, mice were injected intraperitoneally (i.p.) with $33 \mu \mathrm{g}$ of VLPs in $100 \mu \mathrm{l}$ endotoxin-free PBS. For DNA immunizations, mice were injected intramuscularly (i.m.) with a combination of $50 \mu \mathrm{g}$ of DNA (pVR1012-EBOVGP $\triangle M L D+p M L V-G a g P o l$ at a 2:1 ratio) and $16 \mu \mathrm{g} \mathrm{CpG}$ in $100 \mu \mathrm{l}$ endotoxin-free PBS. For CpG immunizations, mice were injected with $16 \mu \mathrm{g}$ CpG in 100 $\mu \mathrm{l}$ endotoxin-free PBS via the i.m. route. The mice were either immunized with VLPs, DNA, a combination of DNA and VLPs, CpG or endotoxin-free PBS (Figure 2). Two weeks after each injection, blood samples were collected by nicking the tails with \#10 Carbon Steel Surgical Blades (Braintree Scientific, Braintree, MA) and collecting blood in BD Microtainer tubes (Becton, Dickinson and Company, Franklin Lakes, NJ). Blood was allowed to clot for 1-2 $\mathrm{h}$ at room temperature, centrifuged at 8,600 $\mathrm{xg}$ for $3 \mathrm{~min}$, and the resulting serum in the supernatant was collected and stored at $-20^{\circ} \mathrm{C}$. The animal protocol and procedures were approved by Institutional Animal Care and Use Committees at the Center for Biologics Evaluation and Research (protocol \#2009-04) in animal facilities accredited by the Association for Assessment and Accreditation of Laboratory Animal Care International. All experiments were performed according to institutional guidelines.

\section{ELISA}

Immuno 96 MicroWell plates (Nunc, Rochester, NY) were coated with $50 \mu \mathrm{l}$ of $1 \mu \mathrm{g} / \mathrm{mL}$ anti-human Fc IgG antibody (Kirkegaard \& Perry Laboratories, Gaithersburg, $\mathrm{MD})$ in PBS overnight at $4{ }^{\circ} \mathrm{C}$. The next day, plates were washed once with PBS and blocked with $100 \mu \mathrm{l}$ of $3 \%$ Bovine Serum Albumin (BSA) in PBS for $1 \mathrm{~h}$ at $37^{\circ} \mathrm{C}$. Plates were then incubated with $50 \mu \mathrm{l}$ of either Fc or $\mathrm{GP}_{1,2}$-Fc $(1 \mu \mathrm{g} / \mathrm{ml})$ [43] in TBS-T (Tris-buffered saline,
$0.1 \%$ Tween-20) for $90 \mathrm{~min}$ at $37^{\circ} \mathrm{C}$. After washing $2 \times$ with TBS-T, $50 \mu \mathrm{l}$ of each serum sample diluted in TBS- $\mathrm{T}$, as indicated in the figures and legends, was added and incubated for $1 \mathrm{~h}$ at $37^{\circ} \mathrm{C}$. Plates were then incubated with $50 \mu \mathrm{l}$ horseradish peroxidase (HRP)-conjugated goat anti-mouse IgG diluted at 1:500 (Pierce, Rockford, IL) for $40 \mathrm{~min}$ at $37^{\circ} \mathrm{C}$ after 2 washes with TBS-T. After washing $4 \times$ with TBS-T, $100 \mu \mathrm{l} /$ well of the ABTS substrate (Kirkegaard \& Perry Laboratories, Gaithersburg, MD) was added for $3 \mathrm{~min}$ at room temperature and plates were read on a VICTOR ${ }^{3} \mathrm{~V}$ plate reader (Perkin Elmer, Shelton, CT) at $405 \mathrm{~nm}$.

\section{Western blot}

Cell lysates for western blots were prepared by transiently transfecting $5 \times 10^{6}$ HEK $293 \mathrm{~T}$ cells/100 mm cell culture dish as previously described [53] except for the following modifications: cells were transfected with $24 \mu \mathrm{g}$ per plate of either pVR1012-EBOVGP, pVR1012-SUDVGP, pVR1012-TAFVGP or pBDBVGP. A mock transfection was also performed with no plasmid DNA. Total protein concentration in the cell lysates was measured by using the Bio-Rad DC Protein Assay Kit (Bio-Rad, Hercules, $\mathrm{CA})$ and $20 \mu \mathrm{g}$ were loaded in each lane on a pre-cast NuPAGE 4-12\% Bis-Tris gel, electrophoresed, and transferred to PVDF membranes, as previously described [53]. The membranes were incubated with one of the following: pooled sera from the VLP group diluted at 1:2,000, pooled sera from the DNA/VLP group diluted at 1:2,000 or an anti- $\mathrm{GP}_{1,2}$ rabbit polyclonal antibody R.F88-2 diluted at $1: 10,000$ [53] Secondary antibody incubation was performed using HRP-conjugated goat anti-mouse IgG $(1: 5,000)$ or goat anti-rabbit IgG $(1: 10,000)$ (Thermo Scientific, Rockford, IL) and developed following the same protocol as above. Another western blot was also performed to titrate the pooled sera from the VLP and DNA/VLP groups at the dilutions of 1:2,000, 1:5,000 and 1:10,000.

\section{Neutralization of rVSV-ZEBOVGP}

The recombinant VSV virus expressing the EBOV $\mathrm{GP}_{1,2}$ [rVSV-ZEBOVGP] or the wild-type VSV were generated as described previously [43]. Briefly, BSR-T7 cells were cotransfected with pBS-N, pBS-P, pBS-L, and pVSVEBOVGP or pVSVFL(+). After $48 \mathrm{~h}$ of incubation at $37^{\circ} \mathrm{C}$, supernatants were collected, titrated on Vero E6, and stored at $-80^{\circ} \mathrm{C}$. For neutralization, VeroE6 cells were seeded at $50 \%$ confluency in 6-well plates and incubated at $37^{\circ} \mathrm{C}$ overnight. rVSV-ZEBOVGP or wild-type VSV (100 pfu) in $45 \mu$ l of medium, which was prepared with or without $5 \%$ guinea pig complement (Accurate Chemical Corp. Westbury, NY), was mixed with mouse serum at the final concentration of 1:25 dilution and incubated overnight at $4{ }^{\circ} \mathrm{C}$. Normal mouse serum pre-diluted at 1:25 was used as the negative control. On the next day, the virus-serum 
mixtures were added to the cells and incubated for $1 \mathrm{~h}$ at $37^{\circ} \mathrm{C}$. Each serum was tested in duplicate samples. After washing two times with medium, the cells were overlaid with medium containing $1 \%$ Bacto-agar and incubated at $37^{\circ} \mathrm{C}$. After $48 \mathrm{~h}$, the cell monolayers were fixed with $10 \%$ TCA and stained with $1 \%$ crystal violet for $30 \mathrm{~min}$. Plaque numbers were used to calculate the titer.

\section{Neutralization of MLV pseudotyped virus bearing envelopes from different viruses}

Retroviral vector pseudotypes were generated by cotransfecting HEK 293T cells as previously described [53] but modified by using the following plasmids: $10 \mu \mathrm{g}$ of pRT43.2nls $\beta$ gal, $2.5 \mu \mathrm{g}$ of pMLV-GagPol and $5 \mu \mathrm{g}$ of the expression plasmid pVR1012-EBOVGP, pVR1012SUDVGP, pVR1012-TAFVGP, pBDBVGP, or pVSV-G. One day prior to neutralization, $4 \times 10^{4}$ cells/well of Vero were seeded in 24-well cell culture plates. The next day, the vector pseudotypes were thawed on ice, incubated with serum at the final concentration of 1:25 dilution for $1 \mathrm{~h}$ at $37^{\circ} \mathrm{C}$, supplemented with $8 \mu \mathrm{g} / \mathrm{mL}$ polybrene (American Bioanalytical, Natick, MA) and $200 \mu \mathrm{L}$ of this mixture replaced the medium on Vero cells. After an overnight culture, supernatants were removed from the wells and replaced with $1 \mathrm{ml}$ of complete culture media. $48 \mathrm{~h}$ after transduction, cells were fixed and histochemically stained for $\beta$-galactosidase activity, and the titer was quantified by microscopic enumeration of blue forming units (BFU), as previously described [54].

\section{Interferon (IFN)- $\gamma$ ELISPOT assay}

Erythrocytes from mice splenocytes were depleted by incubating in 1× BD PharmLyse Buffer (Becton, Dickinson and Company, Franklin Lakes, NJ) for $5 \mathrm{~min}$ at room temperature according to manufacturer's instructions. The splenocytes were then used in an IFN- $\gamma$ ELISPOT assay as previously described [55] except for the following modifications: 500,000 splenocytes per well were stimulated with $50 \mu \mathrm{l}$ of $2 \mu \mathrm{g} / \mathrm{ml}$ ZGP-1, ZGP-4, ZGP-5 or a no-peptide negative control and $0.5 \mu \mathrm{g} / \mathrm{ml}$ biotinylated anti-mouse IFN- $\gamma$ (Clone R4-6A2) (BD Pharmingen, Franklin Lakes, NJ) was added per well in the staining process. Three replicates were used for each combination.

\section{Statistical analysis}

To evaluate statistical significance of the ELISPOT results, we evaluated both within-group and between-group treatment difference. For the within-group comparison, three replicates for each sample were averaged and the difference between these averaged responses with respect to treatment was tested using the paired $t$-test. For the between-group comparison, the treatment difference for each mouse was obtained by taking the difference between treated vs. untreated averaged response (averaged over three replicates). This individual treatment difference was then used to compare the treatment effect between groups. Two-sample $t$-test was used for each two-group comparison.

\section{Acknowledgements}

We thank Julia Misplon and Chia-Yun Lo for their advice and input into the design of some of the immunologic evaluations performed in these studies. This research was partially supported by an inter-agency agreement with the Biomedical Advanced Research and Development Authority (BARDA). In addition, we thank Ronald Rabin and Andrew Byrnes for their critical review of the manuscript.

The content of this publication does not necessarily reflect the views or policies of the US Department of Health and Human Services or of the institutions and companies affiliated with the authors.

\section{Author details}

${ }^{1}$ Division of Cellular and Gene Therapies, Center for Biologics Evaluation and Research, Bldg. 29B, Room 5NN22, 8800 Rockville Pike, Bethesda, MD 20892, USA. ${ }^{2}$ Division of Emerging and Transfusion Transmitted Diseases, Center for Biologics Evaluation and Research FDA, Bethesda, MD, USA. ${ }^{3}$ Biometric Research Branch, National Cancer Institute, Rockville, MD, USA. ${ }^{4} \mathrm{NIH} / \mathrm{NIAID}$, Integrated Research Facility at Fort Detrick, Frederick, MD, USA. ${ }^{5}$ Division of Therapeutic Proteins, Office of Biotechnology Products, Center for Drug Evaluation and Review, FDA, Bethesda, MD, USA.

\section{Authors' contributions}

WO and CAW conceived and designed the experiments; WO, JD and JJ performed the experiments; JS performed statistical analysis; GP, JHK, WW, DV and GK provided materials, advice and technical assistance; WO, JD and CAW drafted the manuscript. All authors read and approved the final manuscript.

\section{Competing interests}

JHK performed this work as an employee of Tunnell Consulting, Inc., a subcontractor to Battelle Memorial Institute under its prime contract with NIAID, under Contract No. HHSN272200200016l.

Received: 29 December 2011 Accepted: 25 January 2012 Published: 25 January 2012

\section{References}

1. Kuhn JH, Becker S, Ebihara H, Geisbert TW, Johnson KM, Kawaoka Y, Lipkin WI, Negredo Al, Netesov SV, Nichol ST, et al: Proposal for a revised taxonomy of the family Filoviridae: classification, names of taxa and viruses, and virus abbreviations. Arch Virol 2010, 155:2083-2103.

2. Ascenzi P, Bocedi A, Heptonstall J, Capobianchi MR, Di Caro A, Mastrangelo E, Bolognesi M, Ippolito G: Ebolavirus and Marburgvirus: insight the Filoviridae family. Mol Aspects Med 2008, 29:151-185.

3. Feldmann $H$, Jones $S$, Klenk HD, Schnittler HJ: Ebola virus: from discovery to vaccine. Nat Rev Immunol 2003, 3:677-685.

4. Geisbert TW, Bausch DG, Feldmann H: Prospects for immunisation against Marburg and Ebola viruses. Rev Med Virol 2010, 20:344-357.

5. Richardson JS, Dekker JD, Croyle MA, Kobinger GP: Recent advances in Ebolavirus vaccine development. Hum Vaccin 2010, 6:439-449.

6. Falzarano D, Geisbert TW, Feldmann H: Progress in filovirus vaccine development: evaluating the potential for clinical use. Expert Rev Vaccines 2011, 10:63-77.

7. Jeffers SA, Sanders DA, Sanchez A: Covalent modifications of the ebola virus glycoprotein. J Virol 2002, 76:12463-12472.

8. Lee JE, Fusco ML, Hessell AJ, Oswald WB, Burton DR, Saphire EO: Structure of the Ebola virus glycoprotein bound to an antibody from a human survivor. Nat 2008, 454:177-182.

9. Francica JR, Varela-Rohena A, Medvec A, Plesa G, Riley JL, Bates P: Steric shielding of surface epitopes and impaired immune recognition induced by the ebola virus glycoprotein. PLOS Pathog 2010, 6:e1001098.

10. Reynard O, Borowiak M, Volchkova VA, Delpeut S, Mateo M, Volchkov VE: Ebolavirus glycoprotein GP masks both its own epitopes and the presence of cellular surface proteins. J Virol 2009, 83:9596-9601. 
11. Dowling W, Thompson E, Badger C, Mellquist JL, Garrison AR, Smith JM, Paragas J, Hogan RJ, Schmaljohn C: Influences of glycosylation on antigenicity, immunogenicity, and protective efficacy of ebola virus GP DNA vaccines. J Virol 2007, 81:1821-1837.

12. Shahhosseini S, Das D, Qiu X, Feldmann H, Jones SM, Suresh MR: Production and characterization of monoclonal antibodies against different epitopes of Ebola virus antigens. J Virol Methods 2007, 143:29-37.

13. Takada A, Ebihara H, Feldmann H, Geisbert TW, Kawaoka Y: Epitopes required for antibody-dependent enhancement of Ebola virus infection. J Infect Dis 2007, 196(Suppl 2):S347-356.

14. Wilson JA, Hevey M, Bakken R, Guest S, Bray M, Schmaljohn AL, Hart MK: Epitopes involved in antibody-mediated protection from Ebola virus. Sci 2000, 287:1664-1666

15. Manicassamy B, Wang J, Jiang H, Rong L: Comprehensive analysis of ebola virus GP1 in viral entry. J Virol 2005, 79:4793-4805.

16. Simmons G, Wool-Lewis RJ, Baribaud F, Netter RC, Bates P: Ebola virus glycoproteins induce global surface protein down-modulation and loss of cell adherence. J Virol 2002, 76:2518-2528.

17. Yang Z, Delgado R, Xu L, Todd RF, Nabel EG, Sanchez A, Nabel GJ: Distinct cellular interactions of secreted and transmembrane Ebola virus glycoproteins. Sci 1998, 279:1034-1037.

18. Dube D, Brecher MB, Delos SE, Rose SC, Park EW, Schornberg KL, Kuhn JH, White JM: The primed ebolavirus glycoprotein (19-kilodalton GP1,2): sequence and residues critical for host cell binding. J Virol 2009, 83:2883-2891.

19. Kuhn JH, Radoshitzky SR, Guth AC, Warfield KL, Li W, Vincent MJ, Towner JS, Nichol ST, Bavari S, Choe H, et al: Conserved receptor-binding domains of Lake Victoria marburgvirus and Zaire ebolavirus bind a common receptor. J Biol Chem 2006, 281:15951-15958.

20. Buonaguro L, Tornesello ML, Buonaguro FM: Virus-like particles as particulate vaccines. Curr HIV Res 2010, 8:299-309.

21. Chackerian B: Virus-like particles: flexible platforms for vaccine development. Expert Rev Vaccines 2007, 6:381-390.

22. Jennings GT, Bachmann MF: The coming of age of virus-like particle vaccines. Biol Chem 2008, 389:521-536.

23. Apostolopoulos $V$, Weiner DB: Development of more efficient and effective DNA vaccines. Expert Rev Vaccines 2009, 8:1133-1134.

24. Dupuy LC, Schmaljohn CS: DNA vaccines for biodefense. Expert Rev Vaccines 2009, 8:1739-1754

25. Liu MA: DNA vaccines: an historical perspective and view to the future. Immunol Rev 2011, 239:62-84

26. Bellier B, Dalba C, Clerc B, Desjardins D, Drury R, Cosset FL, Collins M, Klatzmann D: DNA vaccines encoding retrovirus-based virus-like particles induce efficient immune responses without adjuvant. Vaccine 2006, 24:2643-2655.

27. Bellier B, Huret C, Miyalou M, Desjardins D, Frenkiel MP, Despres P, Tangy F, Dalba C, Klatzmann D: DNA vaccines expressing retrovirus-like particles are efficient immunogens to induce neutralizing antibodies. Vaccine 2009, 27:5772-5780.

28. Desjardins D, Huret C, Dalba C, Kreppel F, Kochanek S, Cosset FL, Tangy F, Klatzmann D, Bellier B: Recombinant retrovirus-like particle forming DNA vaccines in prime-boost immunization and their use for hepatitis $C$ virus vaccine development. J Gene Med 2009, 11:313-325

29. Chang DC, Liu WJ, Anraku I, Clark DC, Pollitt CC, Suhrbier A, Hall RA Khromykh AA: Single-round infectious particles enhance immunogenicity of a DNA vaccine against West Nile virus. Nat Biotechnol 2008, 26:571-577.

30. Chege GK, Shephard EG, Meyers A, van Harmelen J, Williamson C, Lynch A, Gray CM, Rybicki EP, Williamson AL: HIV-1 subtype C Pr55gag virus-like particle vaccine efficiently boosts baboons primed with a matched DNA vaccine. J Gen Virol 2008, 89:2214-2227.

31. Dalba C, Bellier B, Kasahara N, Klatzmann D: Replication-competent vectors and empty virus-like particles: new retroviral vector designs for cancer gene therapy or vaccines. Mol Ther 2007, 15:457-466.

32. Martin JE, Sullivan NJ, Enama ME, Gordon IJ, Roederer M, Koup RA, Bailer RT, Chakrabarti BK, Bailey MA, Gomez PL, et al: A DNA vaccine for Ebola virus is safe and immunogenic in a phase I clinical trial. Clin Vaccine Immunol 2006, 13:1267-1277.

33. Mellquist-Riemenschneider JL, Garrison AR, Geisbert JB, Saikh KU, Heidebrink KD, Jahrling PB, Ulrich RG, Schmaljohn CS: Comparison of the protective efficacy of DNA and baculovirus-derived protein vaccines for EBOLA virus in guinea pigs. Virus Res 2003, 92:187-193.
34. Sullivan NJ, Geisbert TW, Geisbert JB, Xu L, Yang ZY, Roederer M, Koup RA Jahrling PB, Nabel GJ: Accelerated vaccination for Ebola virus haemorrhagic fever in non-human primates. Nat 2003, 424:681-684.

35. Sullivan NJ, Sanchez A, Rollin PE, Yang ZY, Nabel GJ: Development of a preventive vaccine for Ebola virus infection in primates. Nat 2000, 408:605-609

36. Sun Y, Carrion R Jr, Ye L, Wen Z, Ro YT, Brasky K, Ticer AE, Schwegler EE, Patterson JL, Compans RW, Yang C: Protection against lethal challenge by Ebola virus-like particles produced in insect cells. Virol 2009, 383:12-21.

37. Warfield KL, Bosio CM, Welcher BC, Deal EM, Mohamadzadeh M, Schmaljohn A, Aman MJ, Bavari S: Ebola virus-like particles protect from lethal Ebola virus infection. Proc Natl Acad Sci USA 2003, 100:15889-15894.

38. Warfield KL, Posten NA, Swenson DL, Olinger GG, Esposito D, Gillette WK, Hopkins RF, Costantino J, Panchal RG, Hartley JL, et al: Filovirus-like particles produced in insect cells: immunogenicity and protection in rodents. J Infect Dis 2007, 196(Suppl 2):S421-429.

39. Kaletsky RL, Simmons G, Bates P: Proteolysis of the Ebola virus glycoproteins enhances virus binding and infectivity. J Virol 2007, 81:13378-13384

40. Mpanju OM, Towner JS, Dover JE, Nichol ST, Wilson CA: Identification of two amino acid residues on Ebola virus glycoprotein 1 critical for cell entry. Virus Res 2006, 121:205-214.

41. Wool-Lewis RJ, Bates P: Characterization of Ebola virus entry by using pseudotyped viruses: identification of receptor-deficient cell lines. J Virol 1998, 72:3155-3160.

42. Ou W, Delisle J, Konduru K, Bradfute S, Radoshitzky SR, Retterer C, Kota K, Bavari S, Kuhn JH, Jahrling PB, et al: Development and characterization of rabbit and mouse antibodies against ebolavirus envelope glycoproteins. J Virol Methods 2011, 174:99-109.

43. Konduru K, Bradfute SB, Jacques J, Manangeeswaran M, Nakamura S, Morshed S, Wood SC, Bavari S, Kaplan GG: Ebola virus glycoprotein Fc fusion protein confers protection against lethal challenge in vaccinated mice. Vaccine 2011, 29:2968-2977

44. Sullivan NJ, Geisbert TW, Geisbert JB, Shedlock DJ, Xu L, Lamoreaux L, Custers JH, Popernack PM, Yang ZY, Pau MG, et al: Immune protection of nonhuman primates against Ebola virus with single low-dose adenovirus vectors encoding modified GPs. PLOS Med 2006, 3:e177.

45. Martinez O, Valmas C, Basler CF: Ebola virus-like particle-induced activation of NF-kappaB and Erk signaling in human dendritic cells requires the glycoprotein mucin domain. Virol 2007, 364:342-354.

46. Saifuddin M, Hedayati T, Atkinson JP, Holguin MH, Parker CJ, Spear GT: Human immunodeficiency virus type 1 incorporates both glycosyl phosphatidylinositol-anchored CD55 and CD59 and integral membrane CD46 at levels that protect from complement-mediated destruction. J Gen Virol 1997, 78(Pt 8):1907-1911.

47. Saifuddin M, Parker CJ, Peeples ME, Gorny MK, Zolla-Pazner S, Ghassemi M, Rooney IA, Atkinson JP, Spear GT: Role of virion-associated glycosylphosphatidylinositol-linked proteins CD55 and CD59 in complement resistance of cell line-derived and primary isolates of HIV-1. J Exp Med 1995, 182:501-509.

48. Spear GT, Lurain NS, Parker CJ, Ghassemi M, Payne GH, Saifuddin M: Host cell-derived complement control proteins CD55 and CD59 are incorporated into the virions of two unrelated enveloped viruses. Human T cell leukemia/lymphoma virus type I (HTLV-I) and human cytomegalovirus (HCMV). J Immunol 1995, 155:4376-4381.

49. Takefman DM, Spear GT, Saifuddin M, Wilson CA: Human CD59 incorporation into porcine endogenous retrovirus particles: implications for the use of transgenic pigs for xenotransplantation. J Virol 2002, 76:1999-2002.

50. Finer MH, Dull TJ, Qin L, Farson D, Roberts MR: kat: a high-efficiency retroviral transduction system for primary human T lymphocytes. Blood 1994, 83:43-50.

51. Olinger GG, Bailey MA, Dye JM, Bakken R, Kuehne A, Kondig J, Wilson J, Hogan RJ, Hart MK: Protective cytotoxic T-cell responses induced by venezuelan equine encephalitis virus replicons expressing Ebola virus proteins. J Virol 2005, 79:14189-14196.

52. Rao M, Bray M, Alving CR, Jahrling $P$, Matyas GR: Induction of immune responses in mice and monkeys to Ebola virus after immunization with liposome-encapsulated irradiated Ebola virus: protection in mice requires CD4(+) T cells. J Virol 2002, 76:9176-9185. 
53. Ou W, King H, Delisle J, Shi D, Wilson CA: Phenylalanines at positions 88 and 159 of Ebolavirus envelope glycoprotein differentially impact envelope function. Virol 2010, 396:135-142.

54. Wilson CA, Eiden MV: Viral and cellular factors governing hamster cell infection by murine and gibbon ape leukemia viruses. J Virol 1991, 65:5975-5982.

55. Tompkins SM, Zhao ZS, Lo CY, Misplon JA, Liu T, Ye Z, Hogan RJ, Wu Z, Benton KA, Tumpey TM, Epstein SL: Matrix protein 2 vaccination and protection against influenza viruses, including subtype H5N1. Emerg Infect Dis 2007, 13:426-435.

doi:10.1186/1743-422X-9-32

Cite this article as: Ou et al: Induction of ebolavirus cross-species immunity using retrovirus-like particles bearing the Ebola virus glycoprotein lacking the mucin-like domain. Virology Journal 2012 9:32.

Submit your next manuscript to BioMed Central and take full advantage of:

- Convenient online submission

- Thorough peer review

- No space constraints or color figure charges

- Immediate publication on acceptance

- Inclusion in PubMed, CAS, Scopus and Google Scholar

- Research which is freely available for redistribution

Submit your manuscript at www.biomedcentral.com/submit 